\title{
Dawid Megger
}

Wydział Nauk Ekonomicznych i Zarządzania

Uniwersytet Mikołaja Kopernika w Toruniu

\section{Wszechwiedza, determinizm i ekonomia austriacka}

$24 / 2018$

Political Dialogues

DOI: http://dx.doi.org/10.12775/DP.2018.007

\begin{abstract}
In this paper I try to outline the relationship between the concepts of omniscience and determinism in the light of the Austrian approach to economic science. In the first point I introduct to my topic. I describe some general and common standpoints on mentioned issues and explain the problem. Next, I try to solve the linguistic and logical problems of defining omniscience. Then I take up the subject of Austrian praxeology and its epistemological implications. My thesis is that in the statement that omniscience implies determinism there is a vicious circle in reasoning.
\end{abstract}

Keywords: omniscience; determinism; Austrian school of economics; Ludwig von Mises; praxeology; uncertainty

Słowa kluczowe: wszechwiedza; determinizm; austriacka szkoła ekonomii; Ludwig von Mises; prakseologia; niepewność

\section{Problem wszechwiedzy $i$ indeterminizmu}

Przyjmuje się często, że możliwość istnienia wszechwiedzy stanowi nieprzekraczalna barierę dla założenia o indeterminizmie ludzkich działań. Twierdzi się, że istnienie istoty wszechwiedzacej zaprzeczałoby wolności woli człowieka jako zdolności do podejmowania wyborów. W tej perspektywie, głosza zwolennicy tej tezy, na człowieku ciąży fatum, które powoduje, że jakiekolwiek celowe zachowania sa dla niego jedynie iluzją. Jest on skazany na uleganie wpływowi niezależnych od siebie sił, a jego przyszłość jest raz na zawsze ustalona. $Z$ tego powodu współistnienie omniscjencji Boga i wolnej woli człowieka nazywa się paradoksem. Tego rodzaju stanowisko zajmuje m.in. jeden $z$ najważniejszych przedstawicieli austriackiej szkoły ekonomii, Ludwig von Mises ${ }^{1}$.

Takie przekonanie, rzecz jasna, przy założeniu o istnieniu wszechwiedzącego

${ }^{1}$ L. von Mises, Ludzkie działanie. Traktat o ekonomii, przeł. W. Falkowski, Instytut Misesa, Warszawa 2011, s. 59-60. 
Boga, podaje w watpliwość sensowność uprawiania nauki takiej, jaka jest ekonomia, ponieważ (z definicji) przedmiotem jej zainteresowania jest właśnie PODEJMOWANIE WYBORÓw w świecie ograniczonych zasobów. Na rzecz odparcia tej argumentacji przytacza się czasem argumenty teologiczne (transcendentalne), które przyjmuja przesłankę o pozaczasowym istnieniu wszechwiedzacego Boga (np. Boecjusz). Pozaczasowo pojęta wszechwiedza niewattliwie nie mierzy się ze wskazana sprzecznościa. Nasze ambicje pozostana jednak bardziej przyziemne: po próbie poprawnego zdefiniowania pojęcia wszechwiedzy w kategoriach podlegajacych argumentacji nieodwołujacej się do założeń teologicznych (fideistycznych, transcendentalnych) wykażemy, że osadzona w czasie wszechwiedza nie implikuje determinizmu, jeśli tylko ma ona być koherentna $z$ Misesowska koncepcja działania jako zachowania celowego i wynikajacca $z$ niej epistemologia (w nawiazaniu do propozycji Hansa-Hermanna Hoppego).

\section{Czym jest wszechwiedza?}

Aby rozwiązać definicyjny problem wszechwiedzy, odwołamy się na początku do analizy językoznawczej zaprezentowanej przez Piotra Sobotkę, który powołuje się na analizy innego językoznawcy, Andrzeja Bogusławskiego:

Jeśli rzeczywistość ujmiemy jako całość tego, co jest lub może być „wiedziane” [...], to tym kimś, kto o niej wie, musi być w ostateczności Istota Wszechwiedząca, tzn. 'ktoś, kto wie, jaka jest wartość logiczna KAŻDEGO SĄDU'².

2 P. Sobotka, Wiedza i wszechwiedza. Czy człowiek może mieć wolna wolę, jeśli Bóg wie wszystko?, „The Linguistic Guide (Poradnik Językowy)" 2011, nr 1, s. 72 .
Wynika stąd, że wiedzy moga więc podlegać jedynie takie sacdy, które posiadają wartość logiczną. Innymi słowy, musza to być tzw. zdania w sensie logicznym $^{3}$. Idacc dalej, musimy wnioskować, że wiedzy sensu stricto podlegaja tylko sądy prawdziwe, skoro $-z$ logicznego punktu widzenia - zdania fałszywe nie mówia nic o świecie, jeśli „świat jest ogółem faktów”, jak pisze Ludwig Wittgenstein ${ }^{4}$, a „prawdziwość polega na zgodności $z$ faktami” (Arystoteles) ${ }^{5}$. Wszechwiedza to zatem znajomość wszystkich faktów - wszystkich zdań prawdziwych.

Czy tak pojęta wszechwiedza obejmuje znajomość przyszłości? Jeżeli wiedzy podlegaja tylko takie zdania w sensie logicznym, którym przysługuje cecha prawdziwości, to to, czy znajomość przyszłości podpada pod pojęcie wszechwiedzy, trzeba rozstrzygnać na podstawie tego, czy istnieja zdania (empiryczne) mówiące o przyszłości i posiadające wartość logiczna prawdy. Z wywodu Arystotelesa wnioskujemy, że twierdzenia prawdziwe zawsze odnoszą się do tego, co jest (istnieje) w sposób konieczny ${ }^{6}$. To zatem, czy przyszłość podlega wiedzy, zależy od przyjęcia bądź odrzucenia założenia o konieczności wystąpienia określonego porządku przyszłych zda-

${ }^{3}$ Zob. np. G. Malinowski, Logika ogólna, PWN, Warszawa 2010, s. 47. A także Arystoteles, Hermeneutyka, 17a: „Nie każda jednak wypowiedź jest zdaniem stwierdzajacym coś, lecz tylko taka, której przysługuje prawdziwość lub fałszywość. Ale nie wszystkim wypowiedziom przysługuje prawdziwość lub fałszywość, bo na przykład prośba jest wypowiedzia, lecz nie jest ani prawdziwa, ani fałszywa” (przeł. K. Leśniak, PWN, Warszawa 2013).

${ }^{4}$ L. Wittgenstein, Tractatus logico-philosophicus, przeł. B. Wolniewicz, PWN, Warszawa 2004, teza 1.1 , s. 5 .

5 Arystoteles, Hermeneutyka, 19a.

${ }^{6}$ Ibidem, 18a-19a. Np. wymowny fragment: „To więc, co jest, jest konieczne, skoro jest, a tego, czego nie ma, koniecznie nie ma, skoro nie ma. Ale nie wszystko, co jest, koniecznie jest, i nie wszystkiego, czego nie ma, koniecznie nie ma" (19a). 
rzeń. Sam filozof odrzuca to założenie i stwierdza:

Jasne więc, że nie wszystko jest czy powstaje z konieczności; pewne fakty zdarzają się przypadkiem i nie bardziej jest prawdziwe, tak jak i nie bardziej jest fałszywe twierdzenie niż przeczenie ${ }^{7}$.

W odniesieniu do takich zdań, które nie dotycza koniecznych stanów rzeczy, nie możemy zatem twierdzić, że sa prawdziwe albo fałszywe. Chociaż cały zwiazek logiczny składajacy się ze sprzecznych zdań typu: „jutro odbędzie się bitwa morska albo się nie odbędzie" (przykład Arystotelesa) musi być prawdziwy, to wprawdzie - gdy uznajemy, że porządkowi przyszłego biegu zdarzeń nie przysługuje cecha konieczności - ,jeden $z$ tych członów może być BARDZIEJ prawdopodobny niż drugi, ale nie może Już być prawdziwy

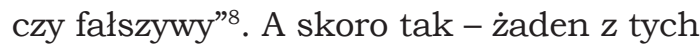
członów, napotykając opór poznawczy istoty poznajacej, nie podlega wiedzy.

\section{Ludzkie działanie jako aksjomat i jego epistemologiczne implikacje}

Powyższe rozważania prowadza nas w sposób konieczny - do epistemicznego problemu sądów o przyszłości. Mises twierdzi, że: „Wszechwiedza oznacza, że wszystkie przyszłe zdarzenia sa już nie-

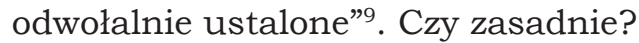

Hans-Hermann Hoppe uważa, że prakseologia (nauka o działaniu), która ukonstytuował w swoich pracach Mises, „stanowi fundament epistemologii"10.

7 Ibidem, 19a.

8 Ibidem.

9 L. von Mises, Ludzkie działanie, s. 59.

${ }^{10}$ H.-H. Hoppe, O prakseologii i prakseologicznych podstawach epistemologii, w: idem, Ekonomia i etyka własności prywatnej, przeł. K. Nowacki, Fijorr Publishing, Warszawa 2016, s. 290-291.
Aksjomatycznie ujęte pojęcie działania jako świadomego dokonywania wyborów łaczy on $z$ drugim aksjomatem - a priori argumentacji. W uzasadnieniu aksjomatyczności tego twierdzenia odwołuje się on do zasady tzw. sprzeczności performatywnej, a więc takiej, w przypadku której próba zaprzeczenia zdania musi implicite zakładać jego słuszność: „Nie można zaprzeczyć, że można argumentować, ponieważ samo zaprzeczenie stanowiłoby argumentacje”11. I dalej: „Nie można też podważać wiedzy o tym, co to znaczy twierdzić, że coś jest prawdziwe czy słuszne, nie zakładajac implicite, że negacja tego twierdzenia jest prawdziwa"12. Jako że każda argumentacja jest rodzajem działania, to wszystko, co mieści się w kategorii działania, musi zostać uznane za koniecznie prawdziwe. Spośród wielu pojęć zawierających się w działaniu, takich jak cel, środki, wartość, koszt czy zysk, na szczególne zainteresowanie zasługuje w tym kontekście przede wszystkim jedno: niepewność przyszłości. Według Misesa:

Niepewność przyszłości zawiera się w samym pojęciu działania. Te dwa fakty że człowiek działa oraz że przyszłość jest niepewna - nie są od siebie niezależne, lecz stanowią dwa różne aspekty tego samego zagadnienia ${ }^{13}$.

Niepewność przyszłości nie oznacza nic innego niż to, że

[...] przed działającym człowiekiem przyszłość jest zakryta. Gdyby człowiek znał przyszłość, nie musiałby dokonywać wyborów i nie podejmowałby działania. Był-

\footnotetext{
11 Ibidem, s. 291.

12 Ibidem, s. 292.

${ }^{13}$ L. von Mises, Ludzkie działanie, s. 90.
} 
by podobny do automatu: reagowałby na bodźce bez udziału własnej woli ${ }^{14}$.

Skoro zatem człowiek wybiera (ma wolę), a wybór oparty na woli wyklucza determinizm (przynajmniej w jego czysto materialistycznej odmianie) ${ }^{15}$, to ludzki rozum - ludzka nauka - napotyka poznawcze ograniczenia w postaci niemożności poznania przyszłych zdarzeń (czyli niemożności sformułowania takich zdań dotyczacych przyszłych empirycznych stanów rzeczy, którym przysługuje wartość logiczna prawdy). Prakseologiczna epistemologia dochodzi więc $\mathrm{w}$ tym zakresie do wniosków zbieżnych $z$ rozumowaniami Arystotelesa: sady o przyszłości nie sa ani prawdziwe, ani fałszywe. Innymi słowy, nie sa one zdaniami w sensie logicznym.

Czy zatem faktycznie wszechwiedza istoty istniejaccej w czasie implikowałaby determinizm i wykluczała działanie? Jak się okazuje, przyjmując twierdzenia prakseologiczne za prawdziwe, nie można tak twierdzić. Jest wręcz odwrotnie: takie twierdzenie zakładałoby determinizm i odrzucało prakseologię. Jest to więc $\mathrm{w}$ istocie problem błędnego koła $\mathrm{w}$ rozumowaniu (circulus vitiosus): ORZEC, ŻE ISTNIENIE W CZASIE ISTOTY WSZECHWIEDZACEJ IMPLIKUJE DETERMINIZM, TO ZAEOŻYĆ DETER$\operatorname{MINIZM}^{16}$.

14 Ibidem.

15 Idem, Teoria a historia. Interpretacja procesów społeczno-gospodarczych, przeł. G. Łuczkiewicz, Instytut Ludwiga von Misesa i PWN, Warszawa 2011 , s. 44.

16 Ten problem działa oczywiście w obie strony: to, jak będziemy rozumieć wszechwiedzę, zależy od przyjętego przez nas założenia o poznawalności bądź niepoznawalności przyszłych stanów rzeczy. Moglibyśmy więc także napisać: stwierdzić, że istniejaca w czasie wszechwiedza nie implikuje determinizmu, to założyć indeterminizm. Tę uwagę zawdzięczam dr. Łukaszowi Dominiakowi.

\section{Podsumowanie}

W tym krótkim artykule staraliśmy się pokazać trudności, jakie wiąża się z pojmowaniem wszechwiedzy w kontekście implikacji epistemologicznych austriackiej prakseologii. Jak się zdaje, dowiedliśmy, że w dotyczącym tego tematu rozumowaniu Misesa tkwi nieusuwalna aporia między wynikającym $z$ jego syste$\mathrm{mu}$ naukowego stanowiskiem poznawczym (niepewność przyszłości) a jego spostrzeżeniami o implikacjach wszechwiedzy. $\mathrm{Na}$ kanwie przedstawionych rozważań o języku, logice i epistemologii doszliśmy do wniosku, że istniejąca w czasie wszechwiedza nie implikuje determinizmu, gdy go uprzednio nie zakładamy. Należy zatem dostrzec, że interpretacja pojęcia wszechwiedzy jest pochodna przyjętych przez nas presupozycji epistemologicznych. Te $z$ kolei w ramach ekonomii austriackiej czynia analizowane przez nas twierdzenie wewnętrznie sprzecznym.

\section{Bibliografia}

Arystoteles, Hermeneutyka, przeł. K. Leśniak, PWN, Warszawa 2013.

Hoppe H.-H., O prakseologii i prakseologicznych podstawach epistemologii, w: idem, Ekonomia $i$ etyka własności prywatnej, przeł. K. Nowacki, Fijorr Publishing, Warszawa 2016, s. 277-306.

Malinowski G., Logika ogólna, PWN, Warszawa 2010.

Mises L. von, Ludzkie działanie. Traktat o ekonomii, przeł. W. Falkowski, Instytut Misesa, Warszawa 2011.

Mises L. von, Teoria a historia. Interpretacja procesów społeczno-gospodarczych, przeł. G. Łuczkiewicz, Instytut Ludwiga von Misesa i PWN, Warszawa 2011. 
Sobotka P., Wiedza $i$ wszechwiedza. Czy człowiek może mieć wolna wole, jeśli Bóg wie wszystko?, „The Linguistic Guide (Poradnik Językowy)" 2011, nr 1, s. 72-83.

Wittgenstein L., Tractatus logico-philosophicus, przeł. B. Wolniewicz, PWN, Warszawa 2004. 